\title{
QUARTOS MOLARES IRROMPIDOS: RELATO DE UM RARO CASO CLÍNICO
}

Letícia Estefanutto SILVEIRA, Monique Stephanie Mendes LOPES, Anna Clara Duszczak D'AGULHAM, Antônio Adilson Soares de LIMA

Dente supranumerário (DSN) é uma alteração na formação de um ou mais dentes que excedem o número normal de elementos da dentição decídua ou permamanente. Podem estar localizados em qualquer região do arco dentário sendo denominado distomolares ou quartos molares quando localizados posteriormente aos terceiros molares. Sua etiologia, apesar de não ser totalmente conhecida, é justificada pela hiperatividade da lâmina dental. $\mathrm{O}$ objetivo deste trabalho é relatar um caso clínico e apresentar as alternativas clínicas. Paciente MAP, sexo feminino, 28 anos, melanoderma, procurou a clínica de semiologia aplicada do Curso de Odontologia para tratamento restaurador. Foi constatada, ao exame clínico e radiográfico, a presença de quartos molares superiores irrompidos bilateralmente, além da presença de algumas lesões cariosas e necessidade de tratamento de disfunção temporomandibular. Apesar de serem na maioria dos casos assintomáticos, os DNS devem ser diagnosticados, se possível de maneira precoce, para elaboração de um correto plano de tratamento, evitando complicações como alterações na erupção, deslocamento dentário, apinhamentos e cistos ou tumores odontogênicos.

Palavras-chave: Dente supranumerário; Quartos molares; Protocolos Clínicos. 